\title{
P-glycoprotein inhibits caspase-8 activation but not formation of the death inducing signal complex (disc) following Fas ligation
}

\author{
AA Ruefli ${ }^{1}$, KM Tainton ${ }^{1}$, PK Darcy ${ }^{1}$, MJ Smyth ${ }^{1}$ and \\ RW Johnstone ${ }^{\star, 1}$ \\ 1 Peter MacCallum Cancer Institute, St. Andrew's Place, East Melbourne, \\ Victoria, Australia \\ * Corresponding author: Tel: 61-3-9656-3727; Fax: 61-3-9656-1411; \\ E-mail: r.johnstone@pmci.unimelb.edu.au
}

Received 15.3.02; revised 24.4.02; accepted 8.5.02 Edited by $\mathrm{H}$ Ichijo

\begin{abstract}
Previous studies by our laboratory have shown that the drug transporter protein P-glycoprotein, P-gp, can specifically inhibit Fas-induced caspase-3 activation and apoptosis. Importantly, inhibition of both caspase-3 activation and cell death could be reversed by pharmacological and antibody inhibitors of P-gp function. However, the molecular mechanisms underpinning P-gp-mediated resistance to Fas-induced cell death and caspase activation remained unknown. We therefore sought to identify the point(s) within the death receptor pathway at which P-gp exerted its inhibitory effect and to determine whether the ATPase activity of P-gp was required. Structure-function analysis determined that ATP hydrolysis was necessary for P-gp to confer resistance to Fasinduced caspase activation and cell death. Importantly, although both FADD and caspase-8 were recruited to the Death Inducing Signal Complex (DISC) in wild-type P-gp expressing cells following Fas ligation, subsequent activation of caspase-8 at the DISC was inhibited. The ability of P-gp to inhibit caspase-8 activation was also ATP dependent. These studies demonstrate that P-gp inhibits Fas-induced caspase-8 activation but not formation of the DISC and that this activity of P-gp is dependent on ATP hydrolysis.

Cell Death and Differentiation (2002) 9, 1266-1272. doi:10.1038/sj.cdd.4401081
\end{abstract}

Keywords: P-glycoprotein; Fas; apoptosis; caspase; death inducing signaling complex

Abbreviations: P-gp, P-glycoprotein; DISC, death inducing signaling complex; MDR, multidrug resistance; TNF, tumornecrosis factor; GFP, green fluorescence protein; FLIP, Flice-like inhibitory protein

\section{Introduction}

P-glycoprotein, (P-gp), is a large (170 kDa) ATP-dependent transporter protein that can confer multidrug resistance (MDR) by actively effluxing drugs from target cells. ${ }^{1}$ Expressed on apical membranes of vital organs and at blood-tissue barriers, P-gp has been shown to protect these tissues from damage induced by xenotoxins. ${ }^{1} \mathrm{P}$-gp is also expressed on hematopoietic cells, however a physiological role in these cells has yet to be identified. Although P-gp has been demonstrated to efflux a wide range of structurally and functionally diverse compounds, no model for the mechanism(s) by which P-gp effluxes cytotoxic drugs can account for its broad specificity. ${ }^{1,2}$ The ATP binding sites within the molecule are well defined and previous studies have determined that both sites are required for transporter activity. ${ }^{3-5}$

In addition to providing resistance to cytotoxic drugs, $\mathrm{P}-\mathrm{gp}^{+\mathrm{ve}}$ multidrug resistant cells are often cross-resistant to a number of cell death stimuli, such as radiation, ${ }^{1,6,7}$ although the mechanism(s) of resistance to these stimuli are not well characterized. We and others have examined the effect of Pgp on apoptosis induced by the tumor necrosis factor (TNF) family of death receptors (Fas, TNFR) ${ }^{8-11}$ We have previously shown that $\mathrm{P}$-gp can specifically inhibit Fas and TNF-induced caspase-3 activation and cell death. Importantly, inhibition of both caspase-activation and cell death were reversed by P-gp antagonists. However, the molecular mechanisms underpinning this novel function of $\mathrm{P}$-gp remained unknown. The order of molecular events during Fas-induced cell death has been intensely studied over the past decade and several steps prior to caspase activation have been identified. We sought to determine the most proximal step(s) during Fas-induced cell death that was affected by P-gp expression. In addition, we examined whether the efflux/ATPase function of P-gp was necessary to confer resistance to Fas-induced cell death.

Overexpression of P-gp using common transfection methods has proven difficult. Therefore, most studies undertaken to examine the role of P-gp in apoptosis have utilized cell lines that have been selected using high doses of chemotherapeutic drugs to induce expression of P-gp. While much useful information has been gathered from these experiments, drug selection can induce a myriad of genetic changes that may directly or indirectly affect sensitivity to cell death stimuli. To counteract this potential problem, we expressed P-gp on the surface of CEM Tleukemia cells by retroviral gene transduction in the complete absence of drug selection. Since we were interested in examining the role of P-gp efflux function in the regulation of Fas-induced apoptosis, we also generated $\mathrm{P}-\mathrm{gp}^{\text {+ve }}$ CEM cells carrying a double mutation in the Walker A repeat regions of P-gp which are essential for ATPase activity and drug efflux function. ${ }^{4}$ The results herein describe the effects of wild-type and mutant P-gp on Fasmediated cell death and define the most proximal point in the Fas-signaling pathway that is affected by P-gp. 


\section{Results}

\section{Expression of wild-type and mutant P-gp by retroviral transduction}

Expression of cell surface wild-type and mutant P-gp and intracellular GFP in retrovirus transduced CEM cells were assessed by flow cytometry (Figure 1A). P-gp was equivalently expressed on the surface of cells infected with wild-type P-gp (CEM $\left.{ }^{G F P}-P-g p^{W T}\right)$ and mutant P-gp (CEM ${ }^{G F P}-P$ $\left.\mathrm{gp}^{\mathrm{MUT}}\right)$, but not on $\mathrm{P}-\mathrm{gp}^{-\mathrm{ve}}$ cells infected with GFP alone $\left(\mathrm{CEM}^{\mathrm{GFP}}\right.$ ) (Figure 1A). All cell lines expressed high levels of intracellular GFP. Expression of wild-type or mutant P-gp had no substantial effect on the relative levels of cell surface Fas compared to CEM GFP cells (Figure $1 \mathrm{~A}$ ).

${ }^{123} \mathrm{R}$ accumulation studies were performed to examine the efflux activity of $C E M^{G F P}-\mathrm{P}-g^{W T}$ and CEM ${ }^{\text {GFP }}-\mathrm{P}-\mathrm{gp}^{\mathrm{MUT}}$. Following incubation of these cells with ${ }^{123} \mathrm{Rh}, \mathrm{CEM}^{\mathrm{GFP}}$-P. $\mathrm{gp}^{\mathrm{WT}}$ cells showed a markedly reduced ${ }^{123} \mathrm{Rh}$ accumulation compared with that seen with CEM ${ }^{\text {GFP }}$ or CEM ${ }^{\text {GFP }}-\mathrm{P}-\mathrm{gp}^{\mathrm{MUT}}$ cells (Figure 1B). Pre-treatment of $C E M^{G F P}-P-g p^{W T}$ cells with the pharmacological P-gp inhibitor verapamil, inhibited ${ }^{123} \mathrm{Rh}$ efflux, as observed by the increase in fluorescence to the levels seen in CEM ${ }^{\text {GFP }}$ or $C E M^{G F P}-P-g^{\text {MUT }}$ cells (Figure 1B). Thus, wild-type P-gp expressed on the surface of CEM cells was capable of effluxing P-gp substrates, while mutantP-gp had no efflux activity.

\section{Expression of wild-type, but not mutant P-gp confers resistance to Fas-induced cell death}

We next assessed the sensitivity of the CEM cells to Fasmediated apoptosis. CEM ${ }^{\text {GFP }}-\mathrm{P}-\mathrm{gp}^{\mathrm{WT}}, \mathrm{CEM}^{\mathrm{GFP}}-\mathrm{P}-\mathrm{gp}^{\mathrm{MUT}}$, and $C E M^{\text {GFP }}$ cells were labeled with ${ }^{51} \mathrm{Cr}$ and then cultured with APO-1-1 anti-Fas antibody and cross-linked with protein A
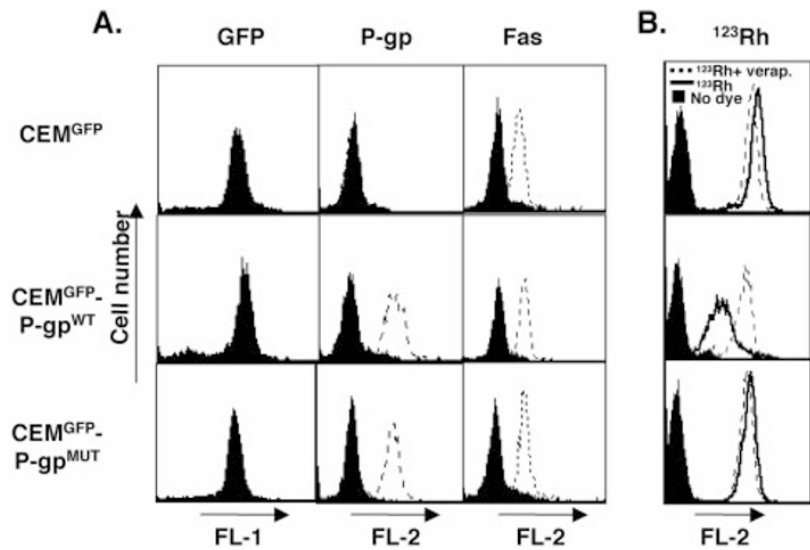

Figure 1 The expression of wild-type and mutant $\mathrm{P}$-gp by retroviral transduction. (A) Expression of GFP (left hand column-shaded histogram) and P-gp (middle column-dashed line) and Fas (right hand column-dashed line) after infection and sorting. CEM cells expressing either wild-type $P$-gp $\left(C E M^{G F P}-P-g p^{\text {WT }}\right)$, mutant P-gp (CEM GFP $-P$-gp $\left.{ }^{M U T}\right)$, or GFP alone (CEM ${ }^{\text {GFP }}$ ), were stained and analyzed by flow cytometry using mAbs specific for human P-gp (MRK16) or Fas (CH-11). Fluorescence staining in each case is compared with cells stained with isotype control mAbs (shaded histograms middle and right hand columns). (B) Cells were incubated without (shaded histogram) or with ${ }^{123} \mathrm{Rh}$ (solid line) for $30 \mathrm{~min}$ and dye uptake was assed by flow cytometry. In some cases cells were pre-treated with $10 \mu \mathrm{M}$ verapamil (dashed line) for $30 \mathrm{~min}$ and then cultured with ${ }^{123} \mathrm{Rh}$ for 0-6 h. CEM ${ }^{\text {GFP }}-\mathrm{P}-\mathrm{gp}^{\mathrm{MUT}}$, and CEM ${ }^{\mathrm{GFP}}$ cells displayed significant cell death after $6 \mathrm{~h}$ incubation with APO-1-1 (Figure $2 \mathrm{~A})$. By contrast and consistent with our previous studies using drug-selected P-gp expressing cells, ${ }^{9}$ cell death induced by Fas antibodies in CEM ${ }^{\text {GFP }}-\mathrm{P}-\mathrm{gp}^{\mathrm{WT}}$ cells was significantly attenuated over both a dose and time range of APO-1-1 (Figure 2A, B). Taken together, these results suggested that $P$ gp ATPase and/or efflux function was necessary to confer resistance to Fas-induced cell death. These data were confirmed using the $\mathrm{CH}-11 \mathrm{lgM}$ anti-Fas monoclonal antibody to cross link the Fas receptor (Figure $2 \mathrm{C}$ ). Consistent with the data shown in Figure $2 A, B$, the CEM ${ }^{G F P}-P-g p^{W T}$ cells were significantly less sensitive to Fas-induced apoptosis compared to the CEM ${ }^{G F P}-P-g p^{M U T}$, and CEM ${ }^{\text {GFP }}$ cells. To determine whether inhibition of Fas-mediated cell death could be reversed using inhibitors of $\mathrm{P}$-gp function, CEM ${ }^{\text {GFP }}-\mathrm{P}$-gp ${ }^{\mathrm{WT}}$, and $C E M^{\text {GFP }}$ cells were pre-treated with either verapamil, or the P-gp-specific antagonistic antibody, UIC-2 and then cultured with $\mathrm{CH}-11$ anti-Fas antibody. Both verapamil and UIC-2 reversed $\mathrm{P}$-gp-mediated inhibition of Fas-induced apoptosis (Figure 2D), demonstrating that inhibition of Faskilling was specifically mediated by $\mathrm{P}$-gp. These results were consistent with those from our previous studies using CEM cells that were induced to overexpress $\mathrm{P}$-gp following selection in the chemotherapeutic drug doxorubicin. ${ }^{9,10}$

\section{Wild-type P-gp inhibits Fas-induced caspase activation}

Following ligation of the Fas receptor at the cell surface, FADD and caspase- 8 are recruited, the DISC is formed and
A.

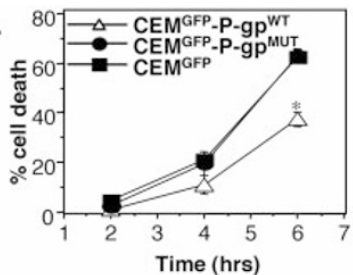

B.

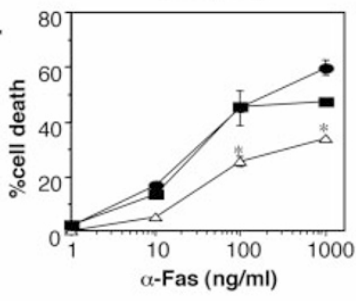

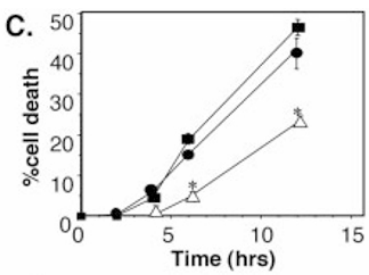

D.

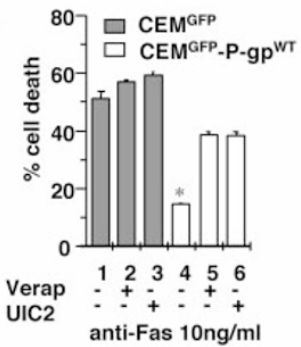

Figure 2 Wild-type, but not mutant P-gp confers resistance to Fas-mediated cell death. CEM cells expressing either wild-type P-gp $\left(C E M^{G F P}-P-g p^{W T}\right)$, mutant P-gp (CEM $\left.{ }^{G F P}-P-g p^{M U T}\right)$, or GFP alone $\left(C E M^{G F P}\right)$, were labeled with ${ }^{51} \mathrm{Cr}$ and then treated for $(\mathbf{A}) 0-6 \mathrm{~h}$. with $100 \mathrm{ng} / \mathrm{ml} \mathrm{APO}-1-1$ anti-Fas antibody and protein $\mathrm{A}$; $(\mathrm{B})$ for $6 \mathrm{~h}$ with $0-1000 \mathrm{ng} / \mathrm{ml}$ APO-1-1 anti-Fas antibody and protein $\mathrm{A}$; (C) $0-12 \mathrm{~h}$. with $10 \mathrm{ng} / \mathrm{ml} \mathrm{CH}-11$ anti-Fas antibody. (D) $\mathrm{CEM}^{\mathrm{GFP}}$ $\mathrm{P}-\mathrm{gp}{ }^{\mathrm{WT}}$ and CEM ${ }^{\mathrm{GFP}}$ cells were labeled with ${ }^{51} \mathrm{Cr}$, pretreated with verapamil $(10 \mu \mathrm{M})$ or monoclonal antibody UIC-2 $(5 \mu \mathrm{g} / \mathrm{ml}) 30 \mathrm{~min}$ and then cultured for $20 \mathrm{~h}$ with $10 \mathrm{ng} / \mathrm{ml} \mathrm{CH}-11$ anti-Fas antibody. For all experiments, data were calculated as the mean \pm S.E. of triplicate samples and are representative of at least three separate experiments and statistical differences $(P<0.001$ as determined by unpaired $t$-test) are denoted by asterisk 
caspase- 8 is auto-activated. ${ }^{12}$ Since only wild-type P-gp inhibited Fas-mediated cell death, we were interested in determining the effects of wild-type and mutant P-gp on caspase activation. Lysates from CEM ${ }^{G F P}-P-g p^{W T}$, $C M^{G F P}-P-g p^{M U T}$, and $C E M^{G F P}$ cells treated with $0-$ $100 \mathrm{ng} / \mathrm{ml}$ APO-1-1 anti-Fas antibody and protein A for $4 \mathrm{~h}$ were assessed for cleavage of caspase-8, caspase-3, and the caspase- 3 substrate, PARP. As seen in Figure $3 A$, cleavage of caspase- 8 to the active p18 protein was significantly

A.

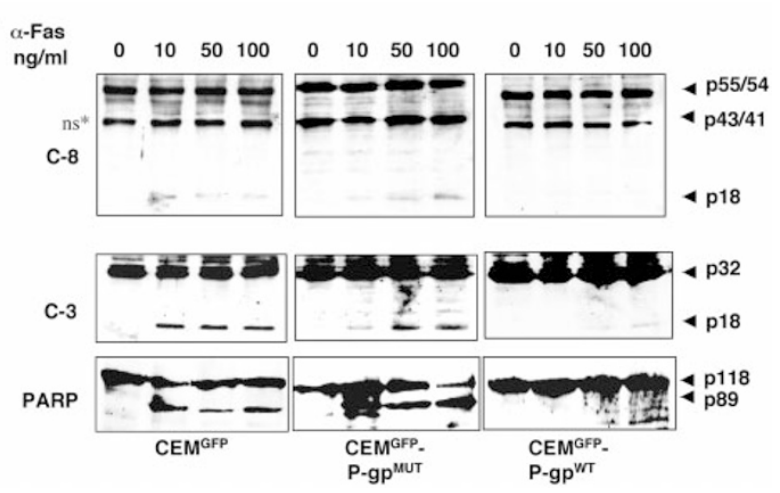

B.

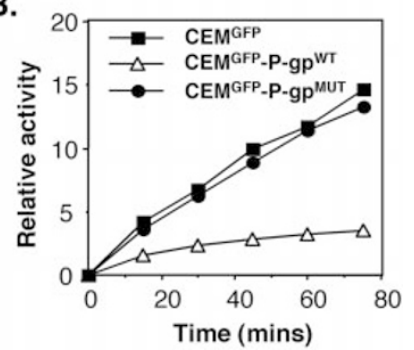

C.

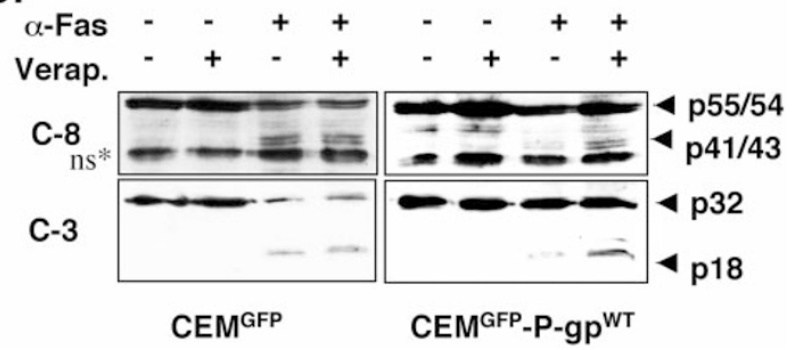

Figure 3 Wild-type $P$-gp inhibits Fas-induced caspase-3 activation. (A) CEM cells expressing either wild-type P-gp (CEM GFP $-P$-gp $\left.{ }^{W T}\right),\left(C E M^{G F P}-P_{-}\right.$ $\mathrm{gp}^{\mathrm{MUT}}$ or GFP alone (CEM ${ }^{\mathrm{GFP}}$ ), were treated for $4 \mathrm{~h}$. with $0-100 \mathrm{ng} / \mathrm{ml}$ APO1-1 anti-Fas antibody and protein $A$. Whole cell lysates were examined for cleavage of PARP, Caspase-8 (C-8) and Caspase-3 (C-3). Arrows indicate the cleavage products. $\mathrm{ns}^{*}$ indicates non-specific bands. (B) Cytosolic lysates from cells treated with $50 \mathrm{ng} / \mathrm{ml}$ APO-1-1 anti-Fas antibody and protein A for $4 \mathrm{~h}$ were incubated with the caspase- 3 substrate Ac-DEVD-pNA and substrate cleavage measured by change in optical density (O.D.). Relative fold activity was determined by dividing O.D. readings of samples treated with anti-Fas antibody by O.D. of control untreated samples. These results are representative of at least three different experiments. (C) To inhibit P-gp function, CEM ${ }^{G F P}-P-g^{W T}$ and CEM GFP cells were pre-treated with $10 \mu \mathrm{M}$ verapamil for $30 \mathrm{~min}$ and then cultured with $50 \mathrm{ng} / \mathrm{ml}$ APO-1-1 anti-Fas antibody and protein A for $6 \mathrm{~h}$. In these experiments, the $43 / 41 \mathrm{kDa}$ proteins were the most clearly detected caspase- 8 cleavage product reduced in CEM ${ }^{\text {GFP }}-\mathrm{P}-\mathrm{gp}^{\mathrm{WT}}$ cells compared with CEM ${ }^{\mathrm{GFP}}$-P. gp $^{\text {MUT }}$, and CEM ${ }^{\text {GFP }}$ cells. In addition, both caspase- 3 and PARP were processed similarly in CEM ${ }^{G F P}-P-g p^{M U T}$, and $\mathrm{CEM}^{\mathrm{GFP}}$ cells while processing of these molecules in CEM ${ }^{G F P}-P-g p^{W T}$ cells was significantly attenuated (Figure $3 A)$. These results indicated that only wild-type P-gp inhibited Fas-mediated caspase activation. These results were confirmed by DEVDase activity assays for caspase-3 activity (Figure 3B). Ligation of the Fas receptor resulted in increased caspase-3 activity in CEM ${ }^{\mathrm{GFP}}-\mathrm{P}-\mathrm{gp}^{\mathrm{MUT}}$ and CEM ${ }^{\mathrm{GFP}}$ cells, however, very little caspase-3 activity was observed in lysates from Fas-treated CEM ${ }^{G F P}-\mathrm{P}-g p^{W T}$ cells.

To determine whether inhibition of caspase activation in CEM ${ }^{G F P}-\mathrm{P}-\mathrm{gp}^{\mathrm{WT}}$ cells could be reversed by blocking P-gp efflux function, cells were pre-treated with verapamil then cultured with APO-1-1 and protein A (Figure 3C). Both caspase-3 and caspase-8 cleavage were enhanced by addition of verapamil to $\mathrm{CEM}^{\mathrm{GFP}}-\mathrm{P}-\mathrm{gp}^{\mathrm{WT}}$ cells, with caspase-8 cleavage increasing from 7 to $39 \%$ and caspase-3 cleavage from 8 to $21 \%$ (Figure $3 \mathrm{C}$ ). Verapamil had no effect on the cleavage of caspase-8 or caspase-3 in $\mathrm{CEM}^{\mathrm{GFP}}$ cells. Taken together these experiments clearly demonstrated that inhibition of caspase cleavage was specifically due to functional $\mathrm{P}$-gp expression since inhibition by either mutation or pharmacological inhibitors restored Fas-induced caspase-activation.

\section{Expression of wild-type or mutant P-gp does not alter expression of FLIP or FADD}

Overexpression of intracellular FLIPS (Flice-like inhibitory proteins) can inhibit Fas-mediated cell death by competing with caspase-8 for binding to FADD and the Fas receptor. ${ }^{13}$ Resistance to Fas-mediated apoptosis has also been associated with deletion of the adapter molecule FADD. ${ }^{14}$ Therefore, it remained possible that the protein levels of the adapter molecule FADD or FLIP were altered in CEM ${ }^{\text {GFP }}-\mathrm{P}$ $\mathrm{gp}^{\mathrm{WT}}$ cells and thereby responsible for the inhibition of caspase activation. To examine these possibilities, Western blot analysis for FADD and FLIP expression was performed on whole cell lysates from the retrovirus transduced cells (Figure 4). As shown in Figure 4, all cells displayed equivalent levels of both FADD and FLIP regardless of P-gp expression. Hence, inhibition of Fas-mediated apoptosis induced by $P$-gp is not due to altered levels of FLIP or FADD in CEM ${ }^{\text {GFP }}-\mathrm{P}$. $\mathrm{gp}^{\mathrm{WT}}$ cells.

\section{Wild-type, but not mutant P-gp inhibits caspase-8 auto-activation and cleavage at the DISC}

Since the expression of wild-type P-gp inhibited processing of caspase-8, the most proximal caspase in the Fas-mediated pathway, it was possible that this occurred at the level of DISC formation. To determine the point at which P-gp was inhibiting Fas-mediated apoptosis, DISC formation was examined in $\mathrm{CEM}^{\mathrm{GFP}}-\mathrm{P}$-gpWT, CEM ${ }^{\mathrm{GFP}}-\mathrm{P}-\mathrm{gp}^{\mathrm{MUT}}$, and CEM ${ }^{\mathrm{GFP}}$ cells. Cells were treated for or $0-20$ min with APO-1-1 anti-Fas antibody, the DISC was immunoprecipitated and Western blots for caspase-8 and FADD were performed (Figure 5). The p55/54 pro-forms of caspase-8 were associated with the Fas- 


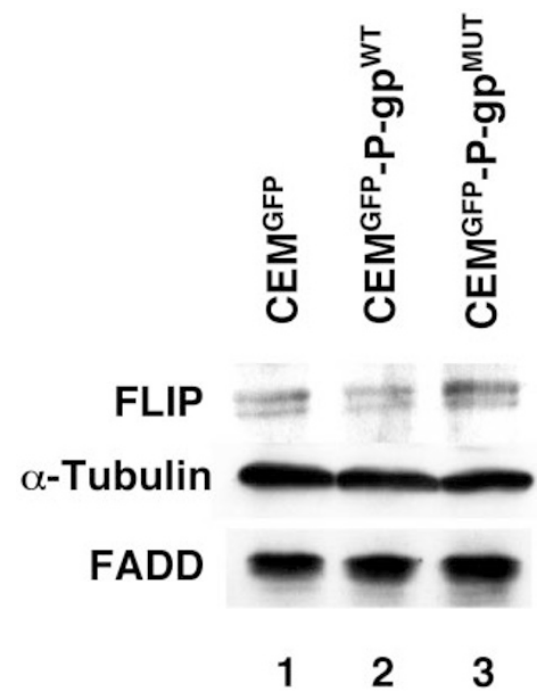

Figure 4 Expression of wild-type or mutant P-gp does not alter expression of FLIP or FADD. Whole cell lysates from CEM cells expressing either wild-type P-gp (CEM GFP - P-gp ${ }^{\text {WT }}$ ), mutant P-gp (CEM ${ }^{G F P}-P$-gp ${ }^{\text {MUT }}$ ), or GFP alone $\left(\mathrm{CEM}^{\mathrm{GFP}}\right)$ were examined for expression of endogenous FADD, FLIP and $\alpha$ tubulin

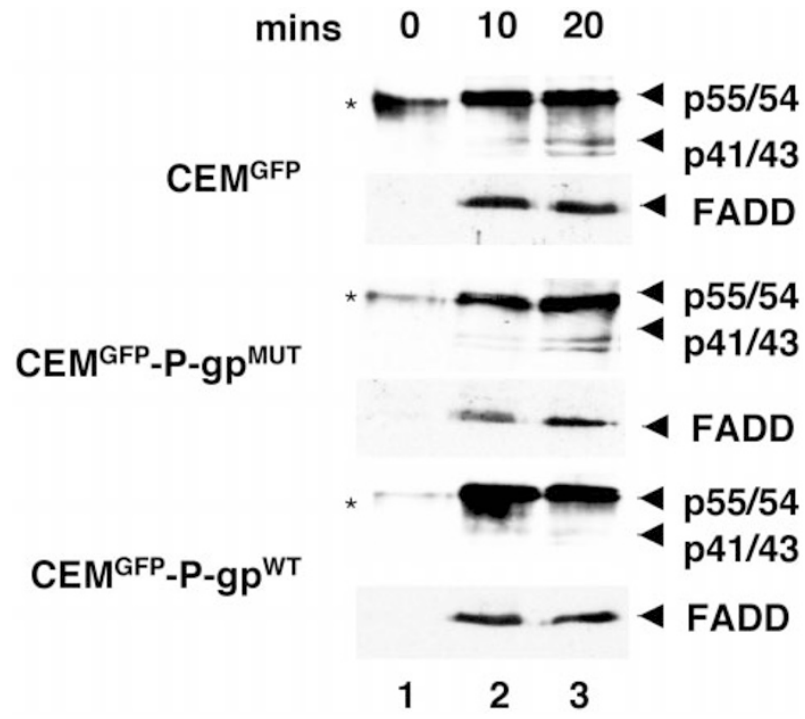

Figure 5 Wild-type, but not mutant P-gp inhibits caspase-8 autoactivation and cleavage at the DISC. CEM cells expressing either wild-type P-gp (CEM ${ }^{G F P}-P_{-g}{ }^{\text {WT }}$ ), mutant P-gp (CEM $\left.{ }^{G F P}-P-g^{M U T}\right)$, or GFP alone $\left(\right.$ CEM $^{\text {GFP }}$ ) were treated for $0-20 \mathrm{~min}$ with $1 \mathrm{~g} / \mathrm{ml}$ APO-1-1 anti-Fas antibody and were immunoprecipitated with protein A sepharose beads. Cells were lysed and IP lysates were then assessed for the presence of caspase- 8 and FADD by Western blot analysis using anti-caspase- 8 and anti-FADD mAbs. Arrows indicate the p55/54 pro-forms of caspase- 8 and processed $p 43 / 41$ caspase-8 still bound to the Fas receptor. Note the $\lg G$ heavy chain denoted by * runs as a band just below the p55 proforms of caspase-8 and can be seen in the $0 \mathrm{~min}$ time point

receptor regardless of P-gp expression (Figure 5). However, processing of caspase-8 to $\mathrm{p} 43 / 41$ products was significantly inhibited in CEM ${ }^{G F P}$-P-gp ${ }^{W T}$ cells. Densitometry analysis revealed that processed caspase- 8 in cells treated for
20 min with anti-Fas antibody represented 34 and $46 \%$ of total bound protein in $\mathrm{CEM}^{\mathrm{GFP}}-\mathrm{P}-\mathrm{gp}^{\mathrm{MUT}}$ cells and $\mathrm{CEM}^{\mathrm{GFP}}$ cells, respectively, compared to just $11 \%$ in CEM ${ }^{\text {GFP }}-\mathrm{P}$-gp ${ }^{\text {WT }}$ cells (Figure 5). Furthermore, equivalent amounts of FADD were associated with the DISC in all cell lines tested, demonstrating that the differences in caspase- 8 activation could not be due to deficient FADD recruitment in CEM ${ }^{\text {GFP }}$-P. $\mathrm{gp}^{\mathrm{WT}}$ cells (Figure 5). Similar results were observed in drugselected P-gp ${ }^{+v e}$ cells (data not shown). Thus, wild-type but not ATPase-defective P-gp inhibits caspase-8 activation following DISC formation but does not affect recuritment of FADD or pro-caspase-8.

\section{Discussion}

The results presented herein demonstrated that wild-type Pgp can inhibit Fas-mediated apoptosis and mutation of specific amino acids necessary for ATPase activity abolished this activity of P-gp. Importantly, these studies revealed that $P$-gp does not interfere with the formation of the DISC since equivalent amounts of pro-caspase- 8 were associated with the Fas-receptor. Rather, we demonstrated that P-gp inhibited the processing and activation of caspase-8. We used a retrovirus system to express $\mathrm{P}$-gp in the complete absence of drug selection; hence our results were not confounded by unknown genetic alterations introduced by drug selection, although data from this study confirmed our earlier studies in drug-selected cells describing the inhibition of Fas-mediated apoptosis by $\mathrm{P}$-gp. ${ }^{9}$

The fact that mutations in the ATP binding regions abolished P-gp-mediated Fas resistance suggests that ATP binding and/or hydrolysis are required for its caspaseinhibitory effects. However, verapamil inhibited efflux function and Fas-resistance (Figure 1B, 2D), yet is known to increase ATPase activity. ${ }^{1}$ It is therefore unlikely that $P$ gp-mediated resistance to $F$ as is due to depletion or alteration of intracellular ATP levels. The ability of P-gp to inhibit Fas-induced apoptosis may hinge on the specific conformation of P-gp within the plasma membrane. Recent studies have demonstrated that $\mathrm{P}$-gp undergoes changes in conformation during the ATP catalytic cycle, which is initiated upon nucleotide binding. ${ }^{15}$ Since mutations within the Walker A repeats abolish ATP binding, mutant P-gp may not be capable of assuming conformational states required to protect against Fas killing. This notion is supported by evidence that $\mathrm{mAb}$ UIC2, which reversed $\mathrm{P}$ gp mediated resistance to Fas, traps $\mathrm{P}$-gp in a transient conformation to inhibit drug efflux function. ${ }^{16}$

To date, viral and cellular FLIPs, cow pox virus CrmA, adenovirus protein E3-14.7 kDa, activation of Protein Kinase C (PKC) and depletion of glutathione have been implicated in resistance to the Fas-mediated cell death pathway by inhibiting activation of caspase-8 through various mechanisms. ${ }^{13,17-21}$ Although the Fas-death receptor pathway is perhaps the best-characterized cell death pathway, all of the components of the Fas-DISC may not be entirely known. Indeed, recent reports have identified other unknown proteins that can bind to and possibly regulate caspase- $8 .^{22}$ Therefore, although it presently remains unclear how $\mathrm{P}$-gp is inhibiting caspase-8 activa- 
tion, it may be regulating an as yet uncharacterized component of the DISC. Clearly the manner by which $\mathrm{P}$ gp regulates cell death and caspase-activation requires further investigation, however, at least two possibilities can be considered given the most recent developments in the model of Fas-induced cell death.

A potential mechanism by which $\mathrm{P}$-gp could regulate Fas-mediated cell death is suggested by recent work implicating both Fas and P-gp in association with components of the actin cytoskeleton. ${ }^{23,24}$ Luciani et al. recently demonstrated that $\mathrm{P}$-gp associates with actin through ezrin, radixin and moesin (ERM) proteins in CEM cells. ${ }^{24}$ This interaction correlated with uropod formation and multi-drug resistance, however, the effects of pharmacological and antibody inhibitors on P-gp-ERM association and uropod formation were not investigated. A separate study demonstrated that Fas associated with ezrin in uropods of CEM cells and activated CD4 ${ }^{+}$T-cells. $^{23}$ Disassociation of Fas and ezrin caused resistance to Fasmediated apoptosis, although the precise events in the signaling pathway that were inhibited (ie, DISC formation, caspase-8 activation) were not explored. Hence, an interaction between P-gp and ezrin may affect a necessary interaction between Fas and ezrin, thereby inducing resistance to Fas-induced apoptosis.

Several groups have shown that Fas forms clusters or caps upon receptor triggering in a ceramide-dependent fashion, ${ }^{25}$ and these clusters are internalized into lipid rafts. ${ }^{26}$ These findings are supported by recent observations by Hueber et al. that Fas is constitutively partitioned into sphingolipid and cholesterol rich membrane rafts. ${ }^{27} \mathrm{P}$ gp can regulate both cholesterol trafficking ${ }^{28}$ and the transport of sphingolipids. ${ }^{29,30}$ Therefore, it remains possible that P-gp may inhibit Fas-mediated apoptosis by disrupting formation of sphingolipid and cholesterol rich membrane rafts, inhibiting signaling events downstream of receptor aggregation and DISC formation.

The physiological relevance of $\mathrm{P}$-gp mediated regulation of Fas-induced cell death remains to be resolved. However, that functional P-gp inhibits Fas-mediated apoptosis in $\mathrm{T}$ cells suggests $\mathrm{P}$-gp may play a physiological role in immune cell functions by controlling cell death and survival. In support of this hypothesis, Gollapudi and co-workers recently reported that treatment with anti-P-gp antibodies induced apoptosis in activated primary human blood mononuclear cells (MNCs). ${ }^{31}$ Cell death was dependent on activation of the Fas receptor pathway, as Fas-Fc, an inhibitor of Fas receptor-Fas ligand interactions, and caspase inhibitors inhibited MNC apoptosis.

In addition to inhibiting cell death, a role for P-gp during cellular differentiation has also been proposed since P-gp expression is down-regulated during differentiation of pluripotent stem cells along the myeloid lineage ${ }^{32}$ and overexpression of $\mathrm{P}$-gp in murine stem cells induces a myeloproliferative syndrome. ${ }^{33}$ Interestingly, Fas and TNFR have been demonstrated to negatively regulate self-renewal of multipotent long-term repopulating hematopoietic stem cells. ${ }^{34}$ Taken together, these findings suggest that $\mathrm{P}$-gp may influence self-renewal decisions in repopulating stem cells by preventing Fas-induced apoptosis.
We and others have demonstrated that P-gp can inhibit Fas-induced apoptosis and caspase-3 activation. ${ }^{9-11,35}$ The studies presented herein are the first to demonstrate that P-gp can inhibit the activation of caspase-8 while not affecting DISC formation and provide an explanation as to why expression of P-gp is associated with loss of Fasinduced caspase-3 activation and apoptosis. Furthermore, we illustrate for the first time that the ATP binding sites within P-gp are necessary to confer resistance to Fasinduced caspase activation and cell death. These findings provide novel molecular detail as to how P-gp can inhibit death-receptor mediated apoptosis.

\section{Materials and Methods}

\section{Cell culture and retroviral gene transduction}

All cells were grown in RPMI medium 1640 supplemented with $10 \%$ ( $\mathrm{vol} / \mathrm{vol}$ ) fetal calf serum, $2 \mathrm{mM}$ glutamine, 100 units $/ \mathrm{ml}$ of penicillin, and $100 \mathrm{mg} / \mathrm{ml}$ of streptomycin (GIBCO, Grand Island, NY). Wildtype and mutant MDR1 coding regions for P-gp were cloned into the retrovirus vector plasmid MSCV, a bicistronic vector expressing green fluorescent protein (GFP). The $4.2 \mathrm{kB}$ EcoR1-EcoR1 fragment from huMDR1 clone huEWT (kindly provided by Paul Roepe, Memorial Sloan Kettering Cancer Center, New York) was cloned into the EcoR1 sites of the MSCV vector (provided by Steve Jane, Bone Marrow Institute, Royal Melbourne Hospital, Melbourne, Victoria). The mutant P-gp used in the following studies contained double lysine to alanine substitutions at amino acids 233 (K433M) and 1076 (K1076M) within the Walker A motifs, which disrupted nucleotide binding, and ATPase and drug-efflux activity. ${ }^{4,16}$ Mutant constructs containing double lysine to alanine substitutions at 433(K433M) and 1076(K1076M) amino acids were generated by excising $4.1 \mathrm{kB}$ Eag1-Eag1 fragment from clone pUCFVXM $\Delta \mathrm{H} 3-$ $\mathrm{Sal}(\triangle \mathrm{AUG})-\mathrm{MDR} / \mathrm{Neo}$ (provided by Igor Roninson, Chicago University, Chicago, IL) and cloned into MSCV vector. To generate high titre virus supernatant, plasmids were co-transfected with an amphotropic 'helper' packaging plasmid pEQ-Pam3(-E) into 293T cells by calcium phosphate precipitation. After $48 \mathrm{~h}$ transfected cells were analyzed by FACs for GFP expression. Supernatants from cells expressing high levels of GFP were stored in aliquots at $-70^{\circ} \mathrm{C}$. CCRF-CEM (CEM) were cultured with viral supernatant and $4 \mu \mathrm{g} / \mathrm{ml}$ polybrene for 3 days, changing media and adding new supernatant and polybrene every $8 \mathrm{~h}$. Transduced cells were sorted using a Becton Dickinson FACs for GFP and P-gp expression using monoclonal antibody (mAb) MRK-16 against P-gp. The highest $10 \%$ of cells expressing GFP and P-gp were then single cell cloned (plated at less than one cell per well in 96 well plate and expanded). The expression of cell surface P-gp and Fas was assessed by flow cytometry using the MRK 16 (Kamiya) anti-P-gp and $\mathrm{CH}-11$ (Upstate Biotechnology) anti-Fas monoclonal antibodies respectively.

\section{Cell death assays}

Three million cells were labeled with ${ }^{51} \mathrm{Cr}$ as previously described. ${ }^{9}$ Cells $\left(2 \times 10^{5} \mathrm{ml}\right)$ were either treated with the following anti-Fas mAbs: clone $\mathrm{CH}-11$ (10 ng/ml); or clone APO-1-1 (0-1000 ng/ml) (Kamiya) cross-linked with Protein A (1/10000 of mAb concentration) (Boeringher Manneheim). In some cases, cells were pre-treated with P-gp inhibitors, verapamil $(10 \mu \mathrm{M})$ or mAb UIC-2 $(5 \mu \mathrm{g} / \mathrm{ml})$. Supernatants were harvested after $2-20 \mathrm{~h}$ and measured for ${ }^{51} \mathrm{Cr}$ 
radioactivity. \% specific lysis=[(experimental release-spontaneous release)/(maximum release-spontaneous release) $] \times 100$. Data are calculated as the mean \pm S.E. of triplicate samples and are representative of at least three separate experiments.

\section{Western blotting}

Cells $\left(5 \times 10^{5}\right)$, either treated with APO-1-1 or $\mathrm{CH}-11$ anti-Fas antibodies as above or untreated, were washed twice in PBS, and lysed on ice for $30 \mathrm{~min}$ in NP40 lysis buffer $(0.5 \% \mathrm{NP}-40,5 \mathrm{mM} \mathrm{MgCl}$, $25 \mathrm{mM} \mathrm{KCl}, 10 \mathrm{mM}$ TrisHCl pH 8.0) containing Complete-mini protease inhibitor cocktail tablets (Roche Molecular Biochemistry, Germany). Cell debris was removed by centrifugation at 13000 r.p.m. for $1 \mathrm{~min}$, and the supernatant retained. Loading of equal amounts of protein was ensured by estimating the protein concentration by Bradford assay. Proteins were separated by SDS-PAGE (10-15\% gels), and transferred onto Immobilon-P nitrocellulose transfer membrane (Millipore Corporation, Bedford, MA, USA), in a Trans-Blot SD semi-dry transfer cell (BioRad, USA). Blots were probed with the following primary antibodies: anti-human caspase-3 mAb (Transduction Laboratories, Lexington, KY, USA); anti-human FLICE mAb (gift from Marcus Peter, University of Heidelberg, Germany); anti-human FADD mAb (Transduction Laboratories); anti-human FLIP rabbit polyclonal (Upstate Biotechnology, Lake Placid, NY, USA); antihuman PARP polyclonal antibody (Boehringer Manneheim); antihuman -tubulin mAb (Sigma, St. Louis, MS, USA). HRP-Rabbit antiMouse or Swine anti-Rabbit (Dako, Glostrup, Denmark) secondary antibodies were added and bound proteins were and visualized by Enhanced Chemiluminescence (ECL) Western Blotting Detection reagents (Amersham Pharmacia Biotech, Buckinghamshire, UK). Per cent cleavage of caspase- 3 and caspase- 8 were determined by densitometry using BioRad Quantity One Software.

\section{DEVDase assays}

Cells $\left(1 \times 10^{6}\right)$ were treated for $4 \mathrm{~h}$ in the presence of $50 \mathrm{ng} / \mathrm{ml}$ APO-11 anti-Fas antibody and protein A. Cells were washed twice in ice-cold PBS and lysed in Nonidet P-40 lysis buffer without protease inhibitors and DEVDase assays were performed as previously described. ${ }^{35}$

\section{Immunoprecipitation of the death inducing signal complex (DISC)}

The amount of DISC-associated caspase-8 and FADD was determined as follows: $\mathrm{P}-\mathrm{gp}^{+\mathrm{ve}}$ and $\mathrm{P}-\mathrm{gp}^{-\mathrm{ve}}$ CEM cells were treated with $1 \mu \mathrm{g} / \mathrm{ml}$ anti-APO-1-1 antibody and Protein $A(0.2 \mathrm{ng} / \mathrm{ml})$ or Protein $\mathrm{A}$ alone for $0-20$ mins at $37^{\circ} \mathrm{C}$. Cells were washed twice with ice-cold PBS and lysed in lysis buffer $[30 \mathrm{mM}$ Tris- $\mathrm{HCl}, \mathrm{pH} 7.5$, $150 \mathrm{mM} \mathrm{NaCl}, 1 \mathrm{mM}$ phenylmethylsulfonyl fluoride and small peptide inhibitors, $1 \%$ Triton X-100 and $10 \%$ glycerol]. Untreated controls were then supplemented with anti-APO-1-1. The Fas-DISC was then precipitated for $4 \mathrm{~h}$ at $4{ }^{\circ} \mathrm{C}$ with protein A-Sepharose (Pharmacia, Freiburg, Germany). After precipitation, beads were washed five times with 20 volumes of lysis buffer. Western blots for caspase-8 and FADD were performed as described above.

\section{Acknowledgements}

The authors thank Igor Roninson, Paul Roepe and Steve Jane for providing reagents, Ralph Rossi for technical support, and Sarah Russell and Joe Trapani for helpful discussions. RW Johnstone is a Wellcome
Trust Senior Research Fellow and MJ Smyth is a Principal Research Fellow of the National Health and Medical Research Council of Australia. This work is supported by a project grant from the NH\&MRC, the AntiCancer Council of Victoria (ACCV) and the Wellcome Trust.

\section{References}

1. Gottesman MM and Pastan I (1993) Biochemistry of multidrug resistance mediated by the multidrug transporter. Ann. Rev. Biochem. 62: 385-427

2. Ambudkar SV, Dey S, Hrycyna CA, Ramachandra M, Pastan I and Gottesman MM (1999) Biochemical, cellular, and pharmacological aspects of the multidrug transporter. Annu. Rev. Pharmacol. Toxicol. 39: 361-398

3. Urbatsch IL, Sankaran B, Bhagat S and Senior AE (1995) Both P-glycoprotein nucleotide-binding sites are catalytically active. J. Biol. Chem. 270: 2695626961

4. Muller M, Bakos E, Welker E, Varadi A, Germann UA, Gottesman MM, Morse BS, Roninson IB and Sarkadi B (1996) Altered drug-stimulated ATPase activity in mutants of the human multidrug resistance protein. J. Biol. Chem. 271: 18771883

5. Senior AE and Bhagat S (1998) P-glycoprotein shows strong catalytic cooperativity between the two nucleotide sites. Biochemistry 37: 831-836

6. Cho J, Lee Y, Lutzky J, Redpath L and Slater L (1995) Collateral sensitivity to radiation and cis-platinum in a multidrug-resistant human leukemia cell line. Cancer Chemother. Pharmacol. 37: 168-172

7. Denecke J, Fiedler K, Hacker-Klom U, Molenkamp G, Jurgens H and Wolff JE (1997) Multiple drug-resistant C6 glioma cells cross-resistant to irradiation. Anticancer Res. 17: 4531-4534

8. Bezombes C, Maestre N, Laurent G, Levade T, Bettaieb A and Jaffrezou JP (1998) Restoration of TNF-alpha-induced ceramide generation and apoptosis in resistant human leukemia KG1a cells by the P-glycoprotein blocker PSC833. FASEB J. 12: 101-109

9. Smyth MJ, Krasovskis E, Sutton VR and Johnstone RW (1998) The drug efflux protein, P-glycoprotein, additionally protects drug-resistant tumor cells from multiple forms of caspase-dependent apoptosis. Proc. Natl. Acad. Sci. USA 95: 7024-7029

10. Johnstone RW, Cretney E and Smyth MJ (1999) P-glycoprotein protects leukemia cells against caspase-dependent, but not caspase-independent, cell death. Blood 93: 1075-1085

11. Matarrese P, Testa U, Cauda R, Vella S, Gambardella L and Malorni W (2001) Expression of P-170 glycoprotein sensitizes lymphoblastoid CEM cells to mitochondria-mediated apoptosis. Biochem. J. 335(Pt 3): 587-595

12. Medema JP, Scaffidi C, Kischkel FC, Shevchenko A, Mann M, Krammer PH and Peter ME (1997) FLICE is activated by association with the CD95 death-inducing signaling complex (DISC). EMBO J. 16: 2794-2804

13. Irmler M, Thome M, Hahne M, Schneider P, Hofmann K, Steiner V, Bodmer JL, Schroter M, Burns K, Mattmann C, Rimoldi D, French LE and Tschopp J (1997) Inhibition of death receptor signals by cellular FLIP. Nature 388: 190-195

14. Zhang J, Cado D, Chen A, Kabra NH and Winoto A (1998) Fas-mediated apoptosis and activation-induced T-cell proliferation are defective in mice lacking FADD/Mort1. Nature 392: 296-300

15. Rosenberg MF, Velarde G, Ford RC, Martin C, Berridge G, Kerr ID, Callaghan R, Schmidlin A, Wooding C, Linton KJ and Higgins CF (2001) Repacking of the transmembrane domains of P-glycoprotein during the transport ATPase cycle. EMBO J. 20: $5615-5625$

16. Mechetner EB, Schott B, Morse BS, Stein WD, Druley T, Davis KA, Tsuruo T and Roninson IB (1997) P-glycoprotein function involves conformational transitions detectable by differential immunoreactivity. Proc. Natl. Acad. Sci. USA 94: $12908-12913$

17. Thome M, Schneider P, Hofmann K, Fickenscher H, Meinl E, Neipel F, Mattmann C, Burns K, Bodmer JL, Schroter M, Scaffidi C, Krammer PH, Peter ME and Tschopp J (1997) Viral FLICE-inhibitory proteins (FLIPs) prevent apoptosis induced by death receptors. Nature 386: $517-521$

18. Srinivasula SM, Ahmad M, Fernandes-Alnemri T, Litwack $G$ and Alnemri ES (1996) Molecular ordering of the Fas-apoptotic pathway: the Fas/APO-1 protease Mch5 is a CrmA-inhibitable protease that activates multiple Ced-3/ICElike cysteine proteases. Proc. Natl. Acad. Sci. USA 93: 14486-14491 
19. Muzio M, Chinnaiyan AM, Kischkel FC, O'Rourke K, Shevchenko A, Ni J, Scaffid C, Bretz JD, Zhang M, Gentz R, Mann M, Krammer PH, Peter ME and Dixit VM (1996) FLICE, a novel FADD-homologous ICE/CED-3-like protease, is recruited to the CD95 (Fas/APO-1) death-inducing signaling complex. Cell 85: 817-827

20. Chen P, Tian J, Kovesdi I and Bruder JT (1998) Interaction of the adenovirus 14.7-kDa protein with FLICE inhibits Fas ligand-induced apoptosis. J. Biol. Chem. 273: $5815-5820$

21. Gomez-Angelats M and Cidlowski JA (2001) PKC regulates FADD recruitment and death-inducing signaling complex formation in FAS/CD95-induced apoptosis. J. Biol. Chem. 276: 44944-44952

22. Bernhard D, Skvortsov S, Tinhofer I, Hubl H, Greil R, Csordas A and Kofler R (2001) Inhibition of histone deacetylase activity enhances Fas receptormediated apoptosis in leukemic lymphoblasts. Cell Death Differ. 8: 1014-1021

23. Parlato S, Giammarioli AM, Logozzi M, Lozupone F, Matarrese P, Luciani $F$, Falchi M, Malorni W and Fais S (2000) CD95 (APO-1/Fas) linkage to the actin cytoskeleton through ezrin in human $\mathrm{T}$ lymphocytes: a novel regulatory mechanism of the CD95 apoptotic pathway. EMBO J. 19: 5123-5134

24. Luciani F, Molinari A, Lozupone F, Calcabrini A, Lugini L, Stringaro A, Puddu P, Arancia G, Cianfriglia M and Fais S (2002) P-glycoprotein-actin association through ERM family proteins: a role in P-glycoprotein function in human cells of lymphoid origin. Blood 99: 641-648

25. Cremesti A, Paris F, Grassme H, Holler N, Tschopp J, Fuks Z, Gulbins E and Kolesnick R (2001) Ceramide enables fas to cap and kill. J. Biol. Chem. 276: 23954-23961

26. GrassmeH, Jekle A, Riehle A, Schwarz H, Berger J, SandhoffK, Kolesnick Rand Gulbins E (2001) CD95 signaling via ceramide-rich membrane rafts. J. Biol. Chem. 276: 20589-20596

27. Hueber AO, Bernard AM, Herincs Z, Couzinet A and He HT (2002) An essential role for membrane rafts in the initiation of Fas/CD95-triggered cell death in mouse thymocytes. EMBO Rep. 3: 190-196
28. Luker GD, Nilsson KR, Covey DF and Piwnica-Worms D (1999) Multidrug resistance (MDR1) P-glycoprotein enhances esterification of plasma membrane cholesterol. J. Biol. Chem. 274: 6979-6991

29. Higgins CF (1994) Flip-flop: the transmembrane translocation of lipids. Cell 79: 393-395

30. van Helvoort A, Smith AJ, Spring H, Fritzsche I, Schinkel AH, Borst P and van Meer G (1996) MDR1 P-glycoprotein is a lipid translocase of broad specificity, while MDR3 P-glycoprotein specifically translocates phosphatidylcholine. Cell 87: $507-517$

31. Gollapudi S and Gupta S (2001) Anti-P-glycoprotein antibody induced apoptosis of activated peripheral blood lymphocytes: a possible role of P-glycoprotein in lymphocyte survival. Clinical Immunology 21: 420-430

32. Chaudhary PM and Robinson IB (1991) Expression and activity of Pglycoprotein, a multidrug efflux pump, in human hematopoietic stem cells. Cell 66: $85-94$

33. Bunting KD, Galipeau J, Topham D, Benaim E and Sorrentino BP (1998) Transduction of murine bone marrow cells with an MDR1 vector enables ex vivo stem cell expansion, but these expanded grafts cause a myeloproliferative syndrome in transplanted mice. Blood 92: 2269-2279

34. Bryder D, Ramsfjell V, Dybedal I, Theilgaard-Monch K, Hogerkorp CM, Adolfsson J, Borge OJ and Jacobsen SE (2001) Self-renewal of multipotent longterm repopulating hematopoietic stem cells is negatively regulated by Fas and tumor necrosis factor receptor activation. J. Exp. Med. 194: 941-952

35. Ruefli AA, Bernhard D, Tainton KM, Kofler R, Smyth MJ and Johnstone RW (2002) Suberoylanilide hydroxamic acid (SAHA) overcomes multidrug resistance and induces cell death in P-gp expressing cells. Int. J. Cancer 99: $292-298$ 